\title{
Takdir Hidup Berdampingan dengan Virus Covid-19: Sebuah Tindakan Preventif Diri Sebelum Ditemukan Penangkalnya
}

\author{
Hanif Hanif \\ Akuntansi, Institut Bisnis dan Informatika Kwik Kian Gie \\ Jalan Yos Sudarso Kav 87. Jakarta 14350 \\ Email:_hanif.ismail@kwikkiangie.ac.id
}

\begin{abstract}
The purpose of writing this article is in the context of community service, which is to offer solutions to reduce the risk of the Covid-19 virus attack, and how to increase immunity by concocting ingredients, which are temporarily called the Covid-19 Preventive Ingredient. The writing of this article was triggered by the complexity of problems that arise in people's lives, not only in people in Indonesia but around the world, which are caused by the Covid-19 virus pandemic. Problems that arise are not only health problems, but the resulting derivative problems, namely the destruction of the social order, economic problems and increased unemployment, caused by the lock down policy or PSBB, and the anxiety and fear it causes in society. Writing articles uses a reflective-subjective approach my own experience. The results of the experience are conveyed by comparing the physical fitness obtained after consuming the ingredients compared to the period before consuming them. A temporary conclusion is that consuming this herb provides better physical fitness.
\end{abstract}

Keywords: community service, Covid-19, increase immunity, the Covid-19 Preventive Ingredient.

\begin{abstract}
Abstrak: Tujuan penulisan artikel adalah dalam rangka pengabdian kepada masyarakat, yakni menawarkan solusi untuk memperkecil risiko terjadinya serangan virus Covid-19, dan bagaimana meningkatkan imunitas dengan meracik ramuan, yang sementara ini disebut Ramuan PreventifCovid-19. Penulisan artikel ini dipicu oleh kompleksitas masalah yang timbul dalam kehidupan masyarakat, tidak hanya di Indonesia tetapi di seluruh dunia, yang diakibatkan pendemi virus Covid-19. Masalah yang timbul tidak hanya masalah kesehatan, tetapi masalah turunan yang diakibatkannya, yakni porakporandanya tatanan sosial, masalah ekonomi dan meningkatnya pengangguran akibat lock down atau PSBB serta kecemasan dan ketakutan yang ditimbulkannya di tengah masyarakat. Penulisan artikel menggunakan pendekatan reflektif-subjektif atas pengalaman diri sendiri. Hasil pengalaman disampaikan dengan membandingkan kebugaran pisik yang diperoleh setelah mengkonsumsi ramuan dibandingkan dengan periode sebelum mengkonsumsinya. Kesimpulan sementara adalah dengan mengkonsumsi ramuan ini memberikan kebugaran yang lebih baik terhadap pisik.
\end{abstract}

Kata kunci: Covid-19, meningkatkan imunitas, pengabdian kepada masyarakat, Ramuan Preventif Covid-19

\section{PENDAHULUAN}

Terus terang, semangat Penulis maju mundur, untuk menuliskan artikel ini, yang didasari pengalaman subjektif Penulis karena ada kekuatiran tulisan ini tidak berguna, bahkan bisa memperkeruh suasana masyarakat dalam menghadapi bahaya virus Covid-19 karena bisa menimbulkan pro dan kontra. Penulis sadar, Penulis bukanlah ahli virus, bukan pula farmakolog atau ahli biologi, dan juga bukan dokter, tetapi orang kebanyakan, orang awam yang tidak paham tentang ilmu virus, dan memiliki latar belakang yang jauh dari bidang itu. Penulis hanyalah akuntan pendidik. Namun, di sisi lain, dorongan menulis ini emakin hari semakin menjadijadi disebabkan dampak bencana virus Covid-19, amat sangat luar biasa, tidak sekedar penyakitnya tetapi masalah turunan yang ditimbulkannya: kecemasan masyarakat, dampak sosial dan ekonomi, pengangguran dan mungkin bagi wilayah dan negara tertentu, bisa menjadi ancaman kelaparan, dan lebih mengenaskan lagi, musibah ini serentak terjadi di seluruh dunia. Siapapun saat ini, memiliki risiko terinfeksi virus Covid-19. 
Oleh karena virus Covid-19 mudah hidup dan berpindah di berbagai benda mati: di gagang pintu, di plastik, di pakaian manusia, di permukaan benda mati lain seperti meja, lap top dan lain sebagainya. Artinya virus Covid-19 sangat mudah bersentuhan dengan kehidupan manusia. Virus ini menyerang saluran pernafasan dan termasuk penyakit menular yang penularannya sangat mudah dan cepat, melalui percikan bersin, atau tangan manusia memegang sesuatu yang di sana ada virus Covid-19, kemudian terbawa ke saluran pernafasan, dan saat kondisi tubuh lemah, bisa menimbulkan infeksi, dan menimbulkan infeksi pernafasan.

Maka banyak negara mengambil tindakan untuk mencegah penularan Covid-19, dengan memotong jalur penyebarannya dengan melakukan lock down: masyarakat dibatasi aktivitasnya dan ruang geraknya, pusat kerumunan ditiadakan dan dilarang, semua orang tidak bisa bebas bergerak untuk bepergian dan pindah dari suatu tempat ke suatu tempat tertentu. Di kota Jakarta misalnya, pemerintah telah menetapkan Pembatasan Sosial Bersekala Besar (PSBB) - sama saja dengan lock down, kemudian memodifikasi kebijakan dengan istilah new normal, dan saat ini 10 September pemerintah DKI kembali mengambil kebijakan PSBB.

Kegelisahan yang mendalam yang menyebabkan Penulis memberanikan diri menuliskan pemikiran ini -setelah mengalami sendiri - begitu mencekamnya dampak dari PSBB di Jabodetabek. Di lingkungan Jabodetabek, korban sosial ekonomi sudah mulai berjatuhan, yakni pemutusan hubungan kerja, pengangguran meningkat tajam, aktivitas ekonomi ambruk: pusat manufaktur dan pusat perdagangan berhenti sampai dengan jangka waktu yang tidak jelas. Tidak perlu pakai teori ekonomi canggih untuk menjelaskannya, maka dapat dipastikan pertumbuhan ekonomi merosost tajam. Menteri Kuangan Republik Indonesia mengemukaan bahwa pertumbuhan ekonomi kuartal II mengalami kontraksi yakni tumbuh $-3,1$ persen. Bahkan banyak ahli ekonomi yakin, ekonomi Indonesia masuk fase resesi ekonomi.

Tidak ada jaminan bahwa virus ini akan hilang dengan sendirinya. Kita hanya bisa berdoa agar ditemukan vaksin yang dapat mencegah infeksi Covid-19. Semoga para ahli virus dapat mengidentifikasi perilaku virus dan ditemukan penangkalnya.

Pertanyaannya adalah sebelum para ahli virus dan farmakolog menemukan vaksin Covid-19, apa yang dapat kita lakukan dalam rangka kita berupaya "beradaptasi" agar kita dapat mengurangi risiko terinfeksi Covid-19, agar kita bisa memulai kegiatan normal-terbatas? Tentu, kita harus patuh dan jalankan himbauan dari para ahli dan pemerintah, kita jalankan protokol kesehatan: hindari kerumunan, selalu jaga jarak [social distancing], jaga kebersihan, dan seterusnya. Mengkonsumsi makanan yang sehat, dengan asupan gizi yang cukup dan olah rada dan istirahat yang cukup. Menghindari kebiasan buruk yang dapat merusak daya tahan tubuh misalnya merokok, dan lain sebagainya.

Artikel ini akan difokuskan pada pengalaman Penulis mengkomsumsi ramuan, yang secara subjektif, terasa lebih menyehatkan. Terutama ramuan ini untuk menjaga kesehatan saluran pernafasan. Keinginan berbagi melalui tulisan ini karena Penulis memang termasuk orang yang mudah mengalami sakit. Lebihlebih sakit yang terkait dengan saluran pernafasan: flu, radang tenggorokan, dan bahkan pneumonia. Jika Penulis ingat kembali, kira-kira minimal 6 kali dalam setahun, pasti mengalami flu dan mengalami radang tenggorokan. Kadang-kadang berlanjut pada radang paru-paru (pneumonia). Terakhir, pada tanggal 10 Agustus 2019 (sebelum ada Covid-19; lebih kurang satu tahun lalu), Penulis dapat serangan pneumonia hebat: sesak, batuk, demam dan batuk berdarah. Ditambah lagi, sudah 1 tahun terakhir Penulis juga kena diabet, dan rutin makan obat diabet dan juga obat kolesterol.

Artikel ini adalah pemikiran subjektif dari Penulis. Tentu pendekatan ini bisa dianggap aneh bagi para ahli sebab yang paling diterima adalah pendekatan objektif. Penulisan artikel subjektif yang disampaikan ini adalah bagaimana interpretasi Penulis atas pengalaman diri sendiri dalam rangka bersikap preventif atas pendemi Covid-19, dalam rangka meningkatkan imunitas tubuh ini. Penulisan artikel mungkin baru bersifat hipotesis saja, belum ada pembuktian. Namun, niat Penulis yang paling utama adalah berbagi pengalaman, mana tahu ada sebagian masyarakat yang merasa cocok dan bisa mengambil manfaatnya.

Selama ini, faktanya kita juga hidup "berdampingan" dengan berbagai virus yang menyebabkan kita sakit influenza dan infeksi pernafasan. Namun, sampai saat ini, tidak ada satu orang ahlipun yang berani meramalkan kapan Covid-19 ini akan reda dan lenyap dari kehidupan manusia. Untuk itulah maka Penulis mencoba berandai-andai, bila yang terburuk yang terjadi, bahwa virus Covid-19 akan tetap eksis dalam kehidupan kita, lalu apa yang harus kita lakukan agar kehidupan sosial kita dapat berjalan normal kembali, 
walaupun dalam bentuk normal baru (new normal). Dengan kata lain bagaimana kita dapat menjalani hidup "berdampingan" berrsama Covid-19 ini? Apa langkah-langkah yang harus ditempuh, agar kita bisa mengurangi atau syukur-syukur terhindar dari musibah pendemi ini.

Fokus penulisan artikel ini adalah bereksperimen dengan membugarkan tubuh dengan mencari-cari ramuan yang mungkin bisa bersifat "preventif" Covid-19. Kata "preventif" dalam tanda kutip dimaksudkan karena pengalaman ini belum tentu benar karena belum diuji secara ilmiah, dan perumusan pemikiran ini lebih kepada perasaan subjektif Penulis sebagai yang bereksperimen dengan ramuan tradisonal dan merasakan hasilnya.

Penulis lebih memikirkan, apa kira-kira sesuatu yang ada di sekitar kita - semacam keraifan lokal yang bisa diambil manfaatnya untuk memperkuat kondisi tubuh, bisa terjangkau oleh semua pihak atau sebuah program yang mampu-laksana untuk setiap orang - sebuah ramuan, yang dapat dikonsumsi masyarakat - bersifat sehari-hari, harga relatif terjangkau, seperti halnya kita minum kopi atau teh?

\section{METODE PELAKSANAAN}

Penulis terinspirasi dari pendekatan sosiologi dalam mengungkap realitas sosial yang terjadi pada masyarakat. Meskipun nanti akan disampaikan suatu ramuan, yang mudah ditemukan, dan bisa dikonsumsi masyarakat banyak, dalam menghadapi badai Covid-19, namun pendekatan sosiologi digunakan sebagai upaya untuk mencari dan mengungkap realitas sosial yakni menggali kebiasan baik dalam menjaga kesehatan dan meningkatkan kondisi tubuh. Pendekatan sosiologi dimungkinkan kita menggunakan pendekatan subjektif, bahkan sangat subjektif [solipsism] (lhat misalnya Burrel \& Morgan, 1979). Subjek dan sekaligus objek penulisan artikel adalah diri Penulis sendiri yang pernah mengalami berbagai penyakit yang telah disampaikan di latar belakang. Penulis yang membuat dan sekaligus mengkonsumsi ramuan tersebut.

Setelah ditemukan ramuan yang dapat memperkuat daya tahan tubuh untuk selanjutnya diuraikan langkah-langkah proses pembuatan ramuan dengan semua prosedurnya. Komposisi ramuan menggunakan ukuran alamiah, sesuai bawaan dari masing-masing unsur ramuan. Ukuran yang digunakan tidak didasarkan pada ukuran baku, atau alat-alat modern seperti timbangan, dan lain sebagainya. Di samping itu, Penulis tidak hanya mengandalkan pendekatan pisik (materi); sesuatu yang terlihat dan terukur saja. Namun, pendekatan gabungan (mix method) antara pendekatan pisik (materi) yang terlihat, dengan pendekatan non pisik (non materi) yakni pendekatan spirit (spiritual). Pendekatan spirit (spiritual) adalah dalam rangka membersihkan pikiran dan meminta petunjuk pada Sang Pencipta, apa kira-kira yang dapat Penulis lakukan. Artinya, pendekatan yang digunakan adalah sinergi antara unsur-unsur materi dan pendekatan spiritualitas yakni berupaya untuk senatiasa khusuk, dan reflektif dengan cara meniadakan diri dalam keberadaan Sang Maha Pencipta dalam rangka mencari kebenaran atas sebuah realitas (Triyuwono, 2012).

\section{HASIL DAN PEMBAHASAN}

Biasanya jika batuk dan radang tenggorokan, Penulis selalu dan selalu pergi ke dokter untuk diperiksa dan diobati. Pasti berujung dengan konsumsi obat antibiotik. Namun, akhir-akhir ini sering terjadi, mungkin karena sudah terlalu sering makan obat antibiotik, obat sudah habis dimakan, tetapi sakit belum pulih. Di saat seperti itu, almarhum Ibu Penulis, dengan sendirinya akan berinisiatif membuat ramuan, yakni:



(Alm) Suarni Muhamad

Ramuan tersebut, kemudian diaduk, lalu diminum. Biasanya beberapa hari setelahnya, batuk hilang dan reda sama sekali. Sembuhnya, tentu karena obat yang telah diberikan dokter plus dari ramuan tersebut, mungkin juga ditambah sugesti karena buatan Sang Ibu. Pengalaman seperti ini, sudah lama Penulis rasakan manfaatnya. Namun, yang perlu dicatat oleh pembaca, sekali lagi, tentu ini adalah pandangan subjektif.

Atas dasar pengalaman itu, Penulis mengingat kembali kebiasan Ibu tersebut, yang dapat Penulis sebut sebagai kearifan lokal, dalam menangani sakit tenggorokan, batuk dan sebagainya. Berangkat dari kondisi pisik Penulis yang telah banyak kelemahan secara kesehatan, tanpa disadari, ikut mempraktikkan kebisaan yang pernah dilakukan oleh almarhum Ibu Penulis itu dalam menanggulangi setiap sakit batuk, tenggorokan, sinusitis.

Apa yang akan Penulis sampaikan ini adalah adopsi dari apa yang telah dipraktikkan oleh almarhum ibu Penulis tersebut. Tentu, yang lebih penting, 
ramuan ini dapat dikonsumsi untuk preventif, untuk memperkuat kondisi tubuh untuk melawan berbagai virus [tidak hanya Covid-19], karena memang suatu kenyataan bahwa sejak dari dahulu, berbagai macam virus sudah ada dalam kehidupan kita sehari-hari kita manusia. Namun demikian, ramuan tersebut Penulis modifikasi dengan komposisi seperti pada Gambar 2.

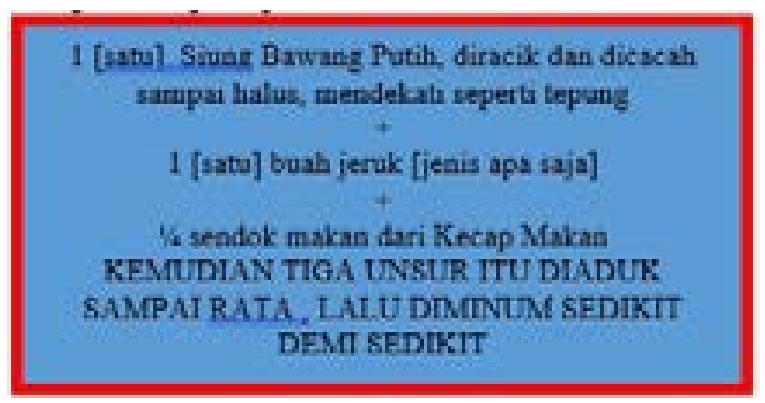

Gambar 2. Modifikasi Ramuan oleh Penulis

Bawang merah dan bawang putih samasama baik untuk dikomsumsi dan memiliki khasiat yang baik untuk kesehatan tubuh manusia. Lebihlebih bawang putih, cepat menstimulus dan menghangatkan tubuh manusia. Ikhsania (2020) mengemukakan bahwa dalam bawang putih (allium sativum) biasanya terdapat 1-10 siung, setiap satu siung bawang putih mentah (3 gram) memiliki banyak manfaat di antaranya menangkal pilek, radang, dan batuk, mengobati jerawat membandel, mengatasi rambut rontok, menurunkan kolesterol, mengendalikan tekanan darah, menjaga kesehatan jantung, menawarkan efek antiradang, meningkatkan kesehatan tulang, mencegah alzheimer dan demensia, menurunkan risiko penyakit kanker (Ikhsania, 2020).

Atas dasar informasi khasiat bawang putih itu, Penulis mulai meracik 1 [satu] siung bawang putih, diracik dan dicacah sampai halus, menjadi bubuk (hampir mendekati seperti tepung), seperti Gambar 3:

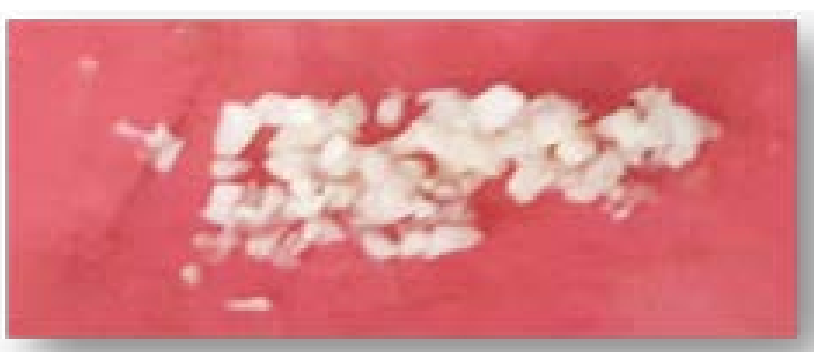

Gambar 3 Hasil Racikan Satu Siung Bawang Putih

Semakin halus racikan bawang putih, maka semakin mudah diaduk dengan hasil perasan satu buah jeruk [jenis apa saja]. Unsur kedua adalah jeruk. Teknis perasan jeruk sedemikian rupa, sehingga jeruk yang diperas sampai dalam, sampai menyentuh lapisan kulit bagian dalam karena kulit jeruk diduga mengandung senyawa golongan flavonoid, yaitu salah satunya hesperidin, yang disinyalir dapat memberikan perlindungan terhadap mikroba dan virus (Irmanida Batubara dalam Adit, 2020). Perasan jeruk seperti pada Gambar 4.



Gambar 4 Hasil Perasan Jeruk

Jeruk yang dipakai, boleh jenis apa saja, kemudian ditambah kecap makan secukupnya \{1/4 sendok makan]. Jadi, tiga unsur ramuan ini dicampur dan diaduk, sampai rata seperti pada Gambar 5.



Gambar 5 Tiga Unsur Ramuan

Setelah diaduk sampai rata, ramuan ini diminum pelan-pelan, seperti kita menyuput kopi atau teh . Cukup satu kali sehari, dan diminum setalah makan karena menurut pengalaman Penulis, ramuan ini juga dapat menaikan asam lambung. Waktunya yang digunakan bebas, misalnya sebelum tidur.

Penulisan hasil dari mengkonsumsi ramuan bawang putih plus jeruk dan kecap hasilnya adalah Penulis tidak mudah mengalami flu dalam waktu yang cukup panjang (sudah enam bulan) - yang biasanya rutin terjadi setiap bulan atau satu kali dalam dua bulan. Penulis meyakini kombinasi pola hidup bersih dan mengkonsumsi ramuan tersebut, serta cukup istirahat dan olah raga cukup, menyebabkan kondisi fisik Penulis menjadi lebih baik.

Namun, bawang putih, memang terasa cukup "keras" dan panas, dtambah pula dengan 
jeruk, tentu ini akan berisiko pada lambung. Untuk itu mohon pelan dan hati-hati memulainya. Misalnya, mungkin cukup dimulai dengan $1 / 2$ siung bawang putih dulu, plus jeruk dan kecap, dan seterusnya. Bagi teman yang ada sakit mag, dan yang mengalami gangguan pencernaan juga harus berhati-hati karena tadi telah disampaikan berdasarkan pengalaman, ramuan ini cepat menaikan asam lambung, dan meningkatkan risiko mengalami diare.

\section{SIMPULAN}

Secara subjektif Penulis merasa kondisi fisik terasa lebih sehat, dan tidak mudah jatuh sakit setelah Penulis rutin mengkonsumsi ramuan bawang putih, jeruk dan kecap. Bahan baku ramuan mudah didapatkan di Indonesia dan mudah dilaksanakan oleh siapa saja, yang terdiri dari bawang putih diracik sampai halus, dicampur dengan jeruk (jenis apa saja) yang telah diperas sampai menyentuh lapisan kulit dalam, kemudian ditambah kecap makan (1/4 sendok makan). Ramuan ini dapat menjadi tambahan stok jenis minuman sehat yang bertujuan untuk mencegah, dan melindungi dari berbagai serangan virus yang terkait dengan pernafasan.

Namun, Penulis tidak menyimpulkan bahwa keadaan fisik Penulis lebih baik karena semata-mata karena ramuan tersebut. Artikel ini, agaknya baru menghasilkan sebuah hipotesis, yakni patut diduga bahwa ramuan tiga unsur bahan: bawang putih, ditambah perasan jeruk plus kecap makan - dapat mengurangi risiko terinfeksi di saluran pernafasan.

Penulisan artikel ini, sangat subjektif, karena berdasarkan pengalaman diri. Diri yang bereksperimen untuk bisa survive dalam masa pendemi ini. Bisa jadi, hasil penulisan artikel ini bisa mengalami bias karena berdasarkan apa yang dirasa oleh Penulis, dan jbelum pernah diukur, sampai sejauh mana pengaruh ramuan ini dalam mengurangi risiko terinfeksi Covid-19. Ditambah lagi, perilaku Penulis dalam kebersihan diri, secara drastis juga berubah. Saat ini, Penulis sering cuci tangan dengan sabun, dan cuci muka dengan sabun dan air panas. Perilaku seperti ini tentu juga akan mengurangi risiko flu dan sejenisnya. Untuk itu, hasil yang dirasa oleh Penulis - tentang keadaan diri - yang semakin baik, belum tentu sepenuhnya oleh ramuan tersebut. Kelemahan penulisan artikel ini adalah ramuan tersebut tidak didasarkan pada bukti, misalnya dari hasil konsumsi dari orang yang pernah mengalami positif Covid-19.

Oleh karena ramuan minuman ini terbuat dari unsur yang baik, maka dapat dicoba oleh masyarakat yang berminat untuk mengkonsumsinya. Harapannya, suatu saat masyarakat sudah terbiasa minum ramuan ini, seperti halnya kebiasaan kita minum kopi atau teh. Kedai kopi atau café, bisa juga kelak menyediakannya. Bila hal itu ada manfaatnya, diharapkan pelan-pelan kehidupan new normal dapat berjalan dengan lebih baik lagi.

Berdasarkan kelemahan hasil penulisan artikel ini, bahwa penulisan artikel ini sangat subjektif, dan berdasarkan refleksi Penulis atas pengalaman, maka disarankan pada Penulis yang ahli di bidang ini selanjutnya untuk menggali secara empiris kandungan dari tiga unsur tersebut : bawang putih + jeruk dan kecap makan.

\section{DAFTAR RUJUKAN}

Adit, A. 2020. Cegah Corona, Guru Besar IPB: Minum Jus Jeruk Plus Kulitnya. https://edukasi.kompas.com/ read/2020/03/27/145731971/cegah-corona-guru-besaripb-minum-jus- jeruk-plus-kulitnya

Burrel, G, M., Gareth (1997). Sociological Paradigms and Organizational Analysis. England: Ashgate Publishing Limite

Ikhsania, A. A. 2020. 10 Manfaat Bawang Putih Mentah, Jantung Lebih Sehat Hingga Turunkan Risiko Kanker. https://www.sehatq.com/artikel/manfaat-bawangputih-mentah-jantung-lebih-sehat-hingga-turunkanrisiko-kanker. Di-download, 24 MEI 2020.

Triyuwono, I (2012). Perspektif, Metodologi, dan Teori Akuntansi syariah. Jakarta: Rajagrafindo Persada 